\title{
SOCIODEMOGRAPHIC AND REPRODUCTIVE PROFILE OF WOMEN WITH ABORTION COMPLICATIONS IN HOSPITAL IN RECIFE
}

\author{
Perfil sociodemográfico e reprodutivo de mulheres com complicações por aborta- \\ mento em hospital no Recife \\ Perfil sociodemográfico y reproductivo de las mujeres con complicaciones de \\ aborto en un hospital en recife
}

Rosielle Costa de Brito ${ }^{1}$, Ana Laura Carneiro Gomes Ferreira², Eduarda Carneiro Gomes Ferreira ${ }^{3}$, Sylvia Marília Aquino do Bú4, Ariani Impieri de Souza ${ }^{5}$

\begin{abstract}
To describe the sociodemographic and reproductive characteristics of women with abortion complications in a tertiary hospital in the city of Recife. A cross-sectional study retrospectively analyzed 569 medical records and found 122 with abortion complications in 2008 to 2010 at Instituto de Medicina Integral Prof. Fernando Figueira. The frequency of abortion complications was $21.4 \%$. The majority of women were between 20 and 35 years old, had eight or more years of schooling, were from Recife and the Metropolitan area, had no previous history of abortion and half of them were married. Among the complications, there was a high frequency of infection $(77.0 \%)$, followed by the need for blood transfusion (15.6\%). It was concluded that women in this study were young, with good education, living in an urban area. The main complication was infection and this could have contributed to abortion complications in maternal morbidity and mortality rates.
\end{abstract}

Keywords: Abortion; Abortion, Septic; Maternal mortality.

\section{RESUMO}

Este estudo objetivou descrever as características sociodemográficas e reprodutivas de mulheres com complicações de aborto em um hospital terciário na cidade de Recife. Estudo descritivo de corte transversal em que foram analisados, retrospectivamente, 569 prontuários de mulheres admitidas com diagnóstico de aborto, dos quais 122 continham registro de complicações no período de 2008-2010, no Instituto de Medicina Integral Prof. Fernando Figueira. A frequência de complicações de aborto foi de $21,4 \%$. A maioria das mulheres tinha entre 20 e 35 anos, oito ou mais anos de estudo, era de Recife e região metropolitana e não tinha história de abortamento anterior; metade das mulheres era casada. Entre as complicações, houve frequência elevada de infecção $(77,0 \%)$, seguida por necessidade de hemotransfusão $(15,6 \%)$. Concluiu-se que as mulheres deste estudo eram jovens, com boa escolaridade e residiam em área urbana. A principal complicação foi infecção, evidenciando a contribuição das complicações do abortamento nos índices de morbimortalidade materna.

Palavras-chave: Aborto; Aborto séptico; Mortalidade materna.

\section{RESUMEN}

Describir las características sociodemográficas y reproductivas de las mujeres con complicaciones de aborto en un hospital de tercer nivel en la ciudad de Recife. Estudio descriptivo de corte transversal, donde se analizaron, retrospectivamente, 569 registros médicos, de los cuales se ha encontrado 122 mujeres con complicaciones de aborto durante el período 2008-2010, en el Instituto de Medicina Integral Prof. Fernando Figueira. La frecuencia de las complicaciones fue de un 21,4\%. La mayoría de las mujeres tenía entre 20 y 35 años de edad y ocho o más años de escolaridad, vivían en la región metropolitana de Recife, no tenían antecedentes de aborto y la mitad de las mujeres estaban casadas. Entre las complicaciones, se registra con mayor frecuencia las infecciones (77,0\%), seguido por la necesidad de transfusión de sangre (15,6\%). Conclusión: las mujeres eran jóvenes, con buena educación y residentes en área urbana. La principal complicación fue la infección.

Palavras-clave: Aborto; Aborto séptico; Mortalidad materna.

\footnotetext{
${ }^{1}$ Mestre em Cuidados Intensivos pelo Instituto de Medicina Integral Prof. Fernando Figueira, enfermeira do Hospital das Clínicas da Universidade federal de Pernambuco(UFPE) - Instituto de Medicina Integral Prof. Fernando Fiqueira (IMIP) - Recife - PE - Brazil - E-mail: rosiellebrito@hotmail.com

${ }^{2}$ Doutorado em Saúde Materno Infantil pelo Instituto de Medicina Integral Prof. Fernando Figueira(IMIP), ginecologista e pesquisadora do Grupo de Pesquisa em Saúde da Mulher do IMIP. - (Medica pesquisadora) - Instituto de Medicina Integral Prof. Fernando Figueira (IMIP) - Recife - PE - Brasil - E-mail: analaura@imip.org.br

${ }^{3}$ Estudante de Medicina da Universidade Federal de Pernambuco (UFPE) e bolsista do Programa Institucional de Bolsas de Iniciação Científica (PIBIC) . - Instituto de Medicina Integral Prof. Fernando Figueira (IMIP) - Recife - PE - Brasil - E-mail: eduardagomesferreira@gmail.com

${ }^{4}$ Estudante de Medicina da Faculdade Pernambucana de Saúde (FPS) - Instituto de Medicina Integral Prof. Fernando Figueira (IMIP) - Recife - PE - Brasil - E-mail: sylviamarilia@hotmail.com

${ }^{5}$ Doutorado em Nutrição pela Universidade Federal de Pernambuco (UFPE), ginecologista e pesquisadora do Grupo de Pesquisa em Saúde da MUlher do IMIP - Instituto de Medicina Integral Prof. Fernando Figueira (IMIP) - Recife - PE - Brasil - E-mail: ariani@imip.org.br
} 


\section{INTRODUCTION}

World widely, it is estimated that about 20 million unsafe abortions occur each year with consequent complications or irreversible sequelae, contributing to the increased maternal morbidity and mortality ${ }^{1}$. Nine out of every thousand women aged between 15 and 44 years were hospitalized for abortion in $2005^{2}$. The treatment for complications related to unsafe abortion, hospitalizes five million women every year. Among the main complications related to unsafe abortion are: hemorrhage, infection, sepsis, and genital trauma ${ }^{3}$.

These complications are among the leading causes of death in women in Brazil, due to the existence of restrictive laws, abortion is often performed in precarious conditions of service ${ }^{4}$. Although it has been observed a decrease in the rates of morbidity and hospitalization for abortion since the 90 's, this decline was more evident between 1992 and 1995, coinciding with the popularization of the use of misoprostol in place of unsafe methods more invasive ${ }^{4}$. Despite the decline observed in the 90's, the complication rates of induced abortion has varied little since then and still are unacceptable levels ${ }^{1}$ In Recife, Northeast of Brazil, the treatment for abortion complications represented $21 \%$ of the total hospital admissions in the period of 2003 to $2007^{5}$. Unsafe abortion and its complications are a serious public health problem in Brazil and in most of Latin America, and its solution remains a challenge that goes beyond the process of legalization ${ }^{6}$. Considering the impact of abortion in the context of public health, especially its complications and sequelae, this study aimed to describe the sociodemographic and reproductive profile of women with complications of abortion in a hospital in the city of Recife between 2008 and 2010.

\section{METHODS}

A descriptive cross-sectional study was conducted at the Instituto de Medicina Integral Prof. Fernando Figueira(IMIP). The sample was composed of 122 medical records of women who had any abortion complication among all 569 women admitted with abortion diagnosis, between January 2008 and December 2010.

Women admitted with a diagnosis of abortion have been identified through patient's file on obstetric emergency and by patient's files. Women with gestational trophoblastic disease, ectopic pregnancy and incompetence isthmus-cervical were excluded from the study. The abortion complications were considered:infection, use of antibiotics, blood transfusion, Intensive Care Unit (ICU) admission, surgical interventions, uterine perforation, shock (septic and/ or hypovolemic), sepsis and death.
Data were collected using an instrument specially designed for this study including information about sociodemografic, reproductive and clinical variables in the medical records. The data analysis was performed by using Epi-Info 3.5.3 software. The absolute distribution and relative frequencies of the variables were described on a table and a graph. The project was approved by the Ethics Committee and Research of the IMIP under the number 2332/11. The term of consentment was dismissed because the data was collected from secondary sources (medical records).

\section{RESULTS}

Among the 569 medical records, 122 were found with abortion complications. The prevalence on complications corresponded to $21.4 \%$ ( $\mathrm{Cl}: 18.2-25.1 \%$ ), in the period of January 2008 to December 2010. To analyze the rate of complications every year, there was no variation in the period studied. The prevalence on complications was $21.4 \%$ in $2008,21.0 \%$ in 2009 and $22.0 \%$ in 2010 .

Regarding to the clinical form of abortion at the time of the discharge, there was a predominance of infected abortion (70.5\%) followed by incomplete abortion (22.1\%), inevitable abortion (5.7\%) and retained abortion (1.6\%).

Table 1 presents the sociodemographic and reproductive women profile with abortion complications. $73.0 \%$ were between 20 and 35 years, and the adolescents accounted for $18 \%$ of the sample. The mean age for women was 25.3 years (SD: 6.6). In relation to schooling, it was observed that more than half had more than eight years of studying $(55.8 \%)$. Half of the women were married or lived in a stable relationship, were unemployed and the majority $(77.8 \%)$ of the women was from Recife and the Metropolitan area of Recife. In relation to the number of previous abortions, $75.4 \%$ of the women had no previous abortion. According to gestational age, the incidence of complications was higher among the late abortions or above 12 weeks of pregnancy $(46.7 \%)$.

Among the complications the infection was highlighted in $77.0 \%$ of the cases. The need for blood transfusions was $15.6 \%$ of the cases. Also, $12.3 \%$ of the women were admitted to ICU obstetric at IMIP, $8.2 \%$ had septic shock and/or hypovolemic (five cases of septic shock and five cases of hypovolemic shock), $2.5 \%$ of the women had sepsis related to abortion and $4.9 \%$ died. There were also four surgical interventions (two cases of laparotomy, one hysterectomy and one correction of vaginal lesion). In one of two cases of uterine perforation, the surgery was not performed because she passed away before the procedure. (Figure 1). 
Table 1. Sociodemographic characteristics and reproductive traits of women hospitalized with abortion complications in IMIP, Recife, Pernambuco, in the period of 2008-2010.

\begin{tabular}{lcc}
\hline Variables & $\mathbf{n = 1 2 2}$ & $\mathbf{\%}$ \\
\hline Age (years) & & \\
$10--19$ & 22 & 18.0 \\
$20--35$ & 89 & 73.0 \\
$>35$ & 10 & 8.2 \\
No Information & 01 & 0.8
\end{tabular}

Schooling (years)

$\begin{array}{lll}\leq 07 & 27 & 22.1 \\ 08-11 & 45 & 36.9 \\ \geq 12 & 23 & 18.9 \\ \text { No Information } & 27 & 22.1\end{array}$

\section{Marital Status}

Single 34

Married/In a stable relationship

No Information 27

$34 \quad 27.9$

\section{Employment status}

Employed 35

Unemployed 61

No Information

26

50.0

Originally From

Recife

43

35.2

Metropolitan area of Recife

52

42.6

Countryside/Other States

26

21.3

No Information

01

\section{Number of Abortions}

0

92

75.4

$01-02$

19

15.6

$\geq 03$

03

2.5

No Information

08

6.5

\section{Number of alive children}

Yes

62

50.8

No

52

No Information

08

6.6

\section{Gestational Age}

$\leq 12$ weeks

$>12$ weeks

No Information

\section{DISCUSSION}

This study found a rate on abortion complications similar to the city of Campinas, Brazil $(23.5 \%)^{7}$ and in Nigeria $(24 \%)^{8}$. It was observed in Thailand, a rate a bit higher with a percentage of $36.8 \%{ }^{9}$. Such high rates on complications are found in countries where abortion is considered illegal, motivating women to use unsafe methods to interrupt an unwanted pregnancy ${ }^{10}$.

$\begin{array}{ll}44 & 36.1 \\ 57 & 46.7 \\ 21 & 17.2\end{array}$

In this study, the complications were more frequent in women in the age group between 20 and 35 years, and this has been the age range most observed in the majority of studies on abortion complications in different regions ${ }^{9,11}$. In general, this is the predominant age group mostly studied on abortion or problems related to pregnancy, as it is considered the ideal age for reproduction. 
Figure 1. Distribution of abortion complications. IMIP, Recife, 2008-2010.

Figure 1: Distribution of abortion complications. IMIP, Recife, 2008-2010.



Schooling usually was used as a proxy in a socioeconomic status and in this study the majority of women had over eight years of schooling. This may reflect to the Brazilian population as having better education, in contrast with the situation of countries on the African continent where the access for women to education is still restricted ${ }^{12}$. A review on studies on induced abortion in different countries has showed predominance in women having more than eight years of schooling ${ }^{13}$. Women with more education may be motivated to stop an unplanned pregnancy and invest in their education or professional growth. On the other hand, in Pakistan about $60 \%$ of women hospitalized for treatment on unsafe abortion complications had no instruction ${ }^{12}$.

Women were mostly from the metropolitan area and Recife concordant with the study to focus on abortion demographically in Brazil which also showed a predominance of women from the urban zone ${ }^{6}$. Generally women who live in large urban centers have greater access to abortion methods, abortion clinics as well as to health services ${ }^{14}$.

Most of the women in this study had no previous abortion and this also occurred in another study at the same service between 2008 and $2010^{15}$. This finding may reflect on the existence of sub-reports on previous abortion, due to restrictive laws about abortion in Brazil like in most countries in Latin America, which makes them less likely to report previous abortions ${ }^{16}$.

The restrictive laws in relation to abortion in most developing countries lead women to use unsafe practices of abortion, competing for a larger occurrence of infections and genital trauma. In this study, the major complication related to abortion was infection, and these data are consistent with other studies that were investigated to severe maternal morbidity associated with abortion ${ }^{9,12}$.

The frequency of complications was higher among women with gestational age above 12 weeks and this may reflect the delay in recognizing the pregnancy as well as, the difficulty to access health services. In contrast of this, other studies observed that complications were more frequent in early abortions ${ }^{9,12}$.
One third of the women presented complications related to abortion, among which highlighted the need for surgical interventions and blood transfusion, septic shock and/or hypovolemic, sepsis and death. Even though these complications do not cause death, it can result in irreversible sequelae to medium and long term as the infertility and chronic pelvic pain, causing major impact on maternal health. Similar results were found in a systematic review on the incidence of severe maternal morbidity associated with abortion, which showed a higher incidence of serious complications when compared to deaths due to abortion ${ }^{17}$.

In addition to the individual and social damage, induced abortion complications have an impact on financial costs on the health sector, increasing the number of hospital admissions as well as inputs used for treatment of these complications $^{18}$.

Although this study has limitations related to the use of secondary files, as well as the lack of classification of abortion, the findings have allowed to identify the main complications related to abortion in a tertiary hospital, reflecting on the regional reality.

\section{CONCLUSION}

Women with abortion complications were young, had good education level, living with a partner and were unemployed. The contribution of these complications in the maternal mortality rates is clear and we recommend the expansion of public health policies aiming to its reduction.

\section{REFERENCES}

1. Grimes DA, Benson J, Singh S, Romero M, Ganatra B, Okaonofua $\mathrm{FE}$, et al. Unsafe abortion: the preventable pandemic. Lancet. 2006;368(9550):1908-19.

2. Sedgh G, Henshaw S, Singh S, Ahman E, Shah IH. Induced abortion: estimated rates trends worldwide. Lancet. 2007;370(9595):1338-45.

3. Haddad LB, Nour NM. Unsafe abortion unnecessary maternal mortality. Rev Obstet Gynecol. 2009;2(2):122-6.

4. Valongueiro SA. Maternal Mortality in Pernambuco, Brazil: What has Change in Tem Years? Reprod Health Matters 2007;15(30):134-44.

5. Instituto de Medicina Social- IMS. Ipas Brazil. Dossiê sobre a realidade do aborto inseguro em Pernambuco: o impacto da ilegalidade do abortamento na saúde das mulheres e nos serviços de saúde de Recife e Petrolina 2007. [on-line] 2007 (acesso 2011 maio 24). Disponível em: <http://www.ipas.org. br/arquivos/pesquisas/factsh.PDF>.

6. Cecatti JG, Guerra GVQL, Sousa MH, Menezes GM. Abortion in Brazil: a demographic approach. Rev. bras. ginecol. obstet. 2010;32(3):105-11.

7. Silva DFO, Bedone AJ, Faúndes A, Fernandes AMS, Moura VGAL. Artificial abortion: is reduction in the frequency and severity of complications a result of the use of misoprostol? Rev. bras. saúde matern. infant. 2010;10(4):441-7. 
8. Henshaw SK, Adewole I, Singh S, Bankole A, Adeniran BO, Hussain M. Severity and cost of unsafe abortion complications treated in Nigerian hospitals. Int Fam Plan Perspect. 2008;34(1):40-50.

9. Andersen K, Ganatra B, Stucke S, Basnett I, Karki YB, Thapa $\mathrm{K}$. A prospective study of complications from comprehensive abortion care services in Nepal. BMC Public Health. 2012;12:9.

10. Osazuwa H, Aziken M. Septic abortion: a review of social and demographic characteristics. Arch Gynecol Obstet. 2007;275(2):117-9.

11. Ramos KS, Ferreira ALCG, Souza Al. Women hospitalized due to abortion in a maternity teaching hospital in Recife, Brazil. Rev. Esc. Enferm. USP. 2010;44(3):605-10.

12. Shah N, Hossain N, Noonari M, Khan NH. Maternal mortality and morbidity of unsafe abortion in a university teaching hospital of Karachi, Pakistan. J Pak Med Assoc 2011;61(6):582-6.

13. Bankole A, Singh S, Haas T. Characteristics of women who obtain induced abortion: a worldwide review. Intern Fam Plann Persp. [on-line]2001 [accessed 2012, Jan 23]; (n.esp): [cerca de 11 p. ]. Available at: http:<//www.guttmacher.org/pubs/ journals/2701001p.pdf>.
14. Instituto de Medicina Social- IMS. Ipas Brasil. Magnitude do aborto no Brasil: Aspectos Epidemiológicos e Sócio-Culturais. 2007(acesso 2011 março 10). 2007. Disponível em: $<$ http://bvsms.saude.gov.br/bvs/publicacoes/magnitude_ aborto_brasil.pdf $>$.

15. Ferreira ALCG, Souza Al, Lima RA, Braga C. Choices on contraceptive methods in post-abortion family planning clinic in the northeast Brazil. Reprod. Health 2010;7:5.

16. Prager SW, Steinauer JE, Foster DG, Darney PD, Drey EA. Risk factors for repeat elective abortion.Am J Obstet Gynecol 2007;197(6):575e1-6.

17. Adler AJ, Filippi V, Thomas SL, Ronsmans C. Incidence of severe acute maternal morbidity associated with abortion: a systematic review. Trop Med Int Health 2012;17(2):177-90.

18. Rasch V. Unsafe abortion and postabortion care - an overview. Acta Obstet Gynecol Scand. 2011;90:692-700 